\title{
Of predators and new men: how ideology matters in constructing military masculinities
}

\author{
Maximilian Kiefer $\mathbb{D}$
}

Received: 14 March 2021 / Revised: 16 November 2021 / Accepted: 23 December 2021 / Published online: 24 January 2022

(C) The Author(s) 2022

\begin{abstract}
There is a growing literature on variations of military masculinities in armed groups which focuses mainly, but not exclusively, on Leftist guerrilla groups. Although these empirical studies deal with military masculinities in highly ideologized contexts, it remains theoretically and conceptually unclear how exactly ideology and masculinity constructions are interrelated. Drawing inspiration from civil war literature, I make the theoretical argument that ideology matters in the form of the military masculinity an armed group seeks to construct. I build on the concept of hegemonic masculinity, highlighting its practice-theoretical implications of which the notion of background knowledge is of particular interest. Here, I locate configurations of masculinity as well as ideology. Conceptualizing armed groups as total institutions, ideology, first, shapes the form of the institution and, secondly, is itself conveyed to combatants via socializing practices. It is via these same socialization processes that not only masculinities are carefully constructed but that these gender constructions are thoroughly shaped by ideological thought. My theoretical argument allows for a more nuanced explanation of ideology and military masculinities and, thus, further adds to broader Feminist debates about their variation. At the end, I illustrate the added value of my theoretical argument with empirical notes on the Salvadoran Frente Farabundo Martí de la Liberación Nacional (FMLN).
\end{abstract}

Keywords Military masculinities · Ideology · Armed groups · Practice theory · Socialization

\footnotetext{
Maximilian Kiefer $(\bowtie)$

Department for International Relations/Peace and Conflict Studies, Institute of Political Science,

University of Tübingen, Tübingen, Germany

E-Mail: maximilian.kiefer@uni-tuebingen.de
} 


\section{Von Räubern und Neuen Menschen: Wie Ideologie die Konstruktion Militärischer Männlichkeit beeinflusst.}

Zusammenfassung In der feministischen Friedens- und Konfliktforschung erfährt die Variation militarisierter Männlichkeiten in bewaffneten Gruppen eine wachsende Aufmerksamkeit. Dabei liegt der Fokus dieser Arbeiten mehrheitlich, zwar nicht ausschließlich, auf linken Guerrilla-Gruppen. Obwohl diese empirischen Studien Männlichkeitskonstruktionen in hoch ideologisierten Kontexten behandeln, erfährt der theoretisch-konzeptionelle Zusammenhang zwischen Ideologie und militärischen Männlichkeiten bislang wenig Beachtung. Durch die Rückbindung an Erkenntnisse der Bürgerkriegsforschung, entfalte ich in diesem Artikel das theoretische Argument, dass Ideologie eine entscheidende Rolle in der Konstruktion militarisierter Männlichkeiten in bewaffneten Gruppen spielt. Aufbauend auf einer praxistheoretischen Lesart des Konzepts der hegemonialen Männlichkeit, verorte ich sowohl Konfigurationen von Männlichkeit als auch Ideologie im Begriff des Hintergrundwissens. Anschließend argumentiere ich, dass in bewaffneten Gruppen, verstanden als totale Institutionen, Ideologie einerseits die spezifische Form der Institution bestimmt, und andererseits Ideologie selbst durch Sozialisationspraktiken vermittelt wird. Durch das Zusammenspiel von Ideologie und Männlichkeiten werden mittels dieser Sozialisationspraktiken ideologisch erwünschte Männlichkeiten konstruiert. Das in dieser Arbeit vorgeschlagene theoretische Argument erlaubt eine nuanciertere Erklärung für das Verhältnis militarisierter Männlichkeiten und Ideologie in bewaffneten Gruppen und trägt damit zur breiteren Debatte über die Variation militärischer Männlichkeiten bei. Abschließend illustriere ich den Mehrwert dieses Modells durch eine kurze Betrachtung der salvadorianischen Guerilla Frente Farabundo Martí de la Liberación Nacional (FMLN).

Schlüsselwörter Militarisierte Männlichkeiten · Ideologie · Bewaffnete Gruppen · Praxistheorie $\cdot$ Sozialisation

[R]ecent research has tended to disregard the ideological Che Guevaras [sic!] in favor of the predatory Charles Taylors. (Kalyvas and Balcells 2010, p. 420)

\section{Introduction}

In the wake of the Cuban Revolution, in 1965, Ernesto Guevara published El Hombre Nuevo, The New Man, in which he described the formation of New Men, men with a clear revolutionary consciousness, as the foundation for his envisioned Socialist society. Since then, his ideas have had a huge impact on many guerrilla groups. For a long time, however, much of the conflict and civil war research has mostly ignored ideology (cf. Kalyvas and Balcells 2010) in favour of a simplistic idea of predatory rebels who prey upon the civilian population and exploit the country's resources. Most influential among these is the greed or grievance debate by Collier and Hoeffler (2004) and Fearon and Laitin (2003). 
Similarly, Feminist peace and conflict studies have brought to light the pivotal role of military masculinities, a violent form of masculinity within militaries and armed groups in the context of civil wars, during the last decades. And although many authors have highlighted the multiplicity of military masculinities (Barrett 1996; Higate 2003), much of the work on variation in military masculinities concentrates on state militaries, mostly in the Global North (Duncanson 2009), and on effects of gender mainstreaming and gender balancing therein (Woodward, Duncanson 2016; Wilén and Heinecken 2018). Only recently, discussions about varying gender regimes and more equal forms of masculinities in the context of non-state armed groups have emerged ${ }^{1}$. Here, studies focus mostly on Leftist guerrilla groups implying an effect of ideology on the specific form of military masculinity (Dietrich Ortega 2012; Gonzalez-Vaillant 2015; Riley 2019, 2020). However, while these empirically rich analyses underline the importance of ideology for military masculinities, how to conceptually and theoretically grasp the relationship between ideology and military masculinities in armed groups remains unclear so far.

In this article, I claim that ideology matters in the construction of the specific form of an armed group's military masculinity by drawing inspiration from civil war literature. To this end, I integrate a practice-theorical understanding of masculinities with the concepts of ideology, total institutions and socialization. Conceptualizing the relationship of an armed group's ideology and the respective military masculinity within that group helps us to better understand the two-dimensional processes of, first, how ideologies shape the gendered, institutional makeup of the armed group itself and, secondly, how, through socialization practices, the gendered ideology leads to the construction of specific forms of military masculinities ${ }^{2}$. Thus, with this article, I not only speak to the aforementioned, emerging literature about alternative, more equal military masculinities in Leftist armed groups. Rather, the proposed conceptualization of the relationship between military masculinities and ideology is fit to travel to other contexts with different political and religious ideologies, such as Jihadist groups. Thus, by adding the factor of ideology to the equation, I contribute to broader debates in Feminist peace and conflict studies about variations of military masculinities in armed groups.

The remainder of this article is structured as follows: in the next section, I briefly summarize previous research on military masculinities and the role of ideology in civil wars. In the third section, I develop my main argument: first, I introduce Connell's (2005) concept of hegemonic masculinity and elaborate on its practicetheoretical implications. Of particular interest is the notion of background knowledge where I locate masculinity as well as ideology (Freeden 2000). Secondly,

\footnotetext{
${ }^{1}$ I use the term 'more equal masculinities' or 'more equal forms of masculinity' loosely to refer to masculinities constructed in those Leftist armed groups which do not rest (solely) on violence and the subordination of women. Rather, they incorporate certain elements of gender equality due to commitment to rather egalitarian ideologies and the incorporation of women. Other authors speak of "alternative masculinities" in this context (cf. Riley 2020).

${ }^{2}$ As I explain in the following section, I am concerned with the relationship of an armed group's ideology and the military masculinity within that institution. That is not to say that societal gender relations and common ideological beliefs do not interact with armed groups' ideologies and their respective gender relations. However, to explore these interactions across different levels is beyond the scope of this article.
} 
I argue that in armed groups, which I conceptually understand as total institutions, ideology works in two directions: on the one hand, ideology affects the form of the total institution, its organizational structure and institutional practices itself. On the other hand, ideology translates into background knowledge via socialization practices and, thus, shapes the construction of military masculinities. The fourth section encompasses a brief empirical example of the guerrilla masculinity in the Salvadoran Frente Farabundo Martí para la Liberación Nacional (FMLN) in order to illustrate the added value of the conceptual argument and to give a first roadmap of its possible empirical application. The concluding fifth section wraps up the results of this study and reconnects them with the existing literature. Here, I present avenues for future research on military masculinities and ideology, for example comparative studies of military masculinities in armed groups across different ideological backgrounds, or how societal gender relations interact with an armed group's ideology and vice versa.

\section{Previous research on military masculinities and ideology in civil wars}

\subsection{Military masculinities}

The concept of military masculinities and its effects on conflict as well as on postconflict reconstruction has risen to great prominence during the last three decades (cf. Morgan 1994; Goldstein 2003). Feminist scholarship has postulated that within militaries and armed groups, a certain form of especially violent and oppressive masculinity is cultivated and becomes hegemonic (cf. next section). According to Barrett (1996, p. 132), military masculinities are characterized by "physical toughness, the endurance of hardships, aggressiveness, a rugged heterosexuality, unemotional logic, and a refusal to complain." Thereby, military masculinities rely on the exaggeration of the stereotypically masculine through the devaluation of what is regarded as feminine.

From early on, scholars have emphasized the multiplicity and often contradictory nature of masculinities (cf. Higate 2003). Therefore, one of the key questions has been how to account for variations of military masculinities. Barrett (1996) finds that military masculinities vary between different branches and ranks of the military according to the technical and strategic demands of their position within the bigger institution. Also, masculinity constructions depend on cultural contexts and operational purposes (Goldstein 2003, p. 266). As Duncanson (2009) shows, the nature of peacekeeping operations affects what soldiers see as ideally manly, leading to an incorporation of traits formerly regarded as feminine such as communication skills, affection and caretaking into the peacekeeping masculinity. Duncanson further argues that more equal military masculinities are achievable by incorporating feminine practices in the first step and then, secondly, constructing a masculinity "through relations of equality and respect, thus dismantling hegemony" (2015, p. 13). However, these studies, and the related debate about the extent to which a "regendering of the military" (Duncanson and Woodward 2016) is possible, tend to be limited to 
state militaries, mostly from the Global North, with the notable exception of Holmes (2014) as well as Wilén and Heinecken (2018).

With regard to non-state armed groups, Riley (2020) shows that there is an emerging strand of literature that deals with variations of masculinities which focuses mostly, but not exclusively, on more equal masculinities within Leftist guerrilla groups. Dietrich Ortega (2012, p. 491) finds that guerrilla groups from Colombia, El Salvador and Peru carefully construct guerrilla masculinities which "are not based on the devaluation of women in general, but on the temporary construction of particular guerrilla femininities, which allow male-female bonding and comradely complicity, and unveil expressions of guerrilla masculinities beyond the predominant association of men with violence". Based on the ideological primacy of class struggle, the groups formed comrade identities that included women as equal fighters for the revolutionary cause while veiling still existing gender inequalities. However, Dietrich Ortega (2012, p. 504) also notes that these expressions of masculinity are only temporal constructions that are likely to disintegrate after the end of armed conflict. Furthermore, evidence from the Nepalese PLA suggests that the Maoists' egalitarian gender ideology allowed for women's participation which in turn shaped male combatants' views on women's participation and rights (Riley 2019). Characteristics which were formerly exclusively reserved for men, like bravery, heroism and military capability, could now be inhabited by female combatants (Riley 2019, p. 560). Gonzalez-Vaillant (2015) similarly finds that women in the Uruguayan Tupamaros were seen as equals as long as they mimicked the heroic guerrillero and occupied this hegemonic male position ${ }^{3}$.

Research on militant Jihadist armed groups reveals equally relevant aspects of how military masculinities and ideologies are intertwined. Aslam (2012, p. 275) argues that Jihadists groups offer retaliation through violent extremism ('Jihad') as a reaffirmation of honor in contexts of marginalization ${ }^{4}$. Similarly, Johnston, Iqbal and True (2020) find that Indonesian Jihadist propaganda constructs a traditional masculinity that promotes violence and the subordination of women based on religious justifications.

Although all these empirical studies deal with military masculinities in highly ideologized contexts and, thus, underline the importance of ideological contents for gender relations in armed groups, it remains theoretically and conceptually unclear how exactly ideology and masculinity constructions are interrelated. With this article, I add to this still young field of research by theorizing the relationship of ideology and military masculinities. Questions I answer are how ideology shapes the institutional (gendered) makeup of the armed group, how combatants are socialized into the group's ideology and how, as an outcome of these processes, military masculinities

\footnotetext{
3 Interestingly, this finding holds true for guerrilla groups in Latin America regardless of the national gender relations as Uruguay was quite progressive at the time, in contrast to other Latin American countries hosting guerrillas.

4 The broader argument Aslam (2012, p. 2) makes is that traditional gender roles in Pakistan can act as a justification for joining Jihadist groups "to alleviate financial hardships and social inadequacies, or simply to embark on an adventurous lifestyle as a stereotypical 'hero' to confirm their 'manliness'." Although being an important insight and further research is necessary, it is not the aim of this article to analyze how a certain gender order conditions the specific ideology a group seeks to adopt.
} 
are infused by ideology. By doing so, I furthermore contribute to the broader debate about variation in military masculinities.

\subsection{The role of ideology in civil wars}

In the following, I sketch out findings from the civil war literature which, on the one hand, underline the importance of ideology in armed conflicts and, on the other hand, offer inspiration for the interaction of ideology and military masculinities.

Ideology plays a pivotal role for understanding armed groups, for example by affecting the level of violence they deploy, their institutional structure and socialization, or their recruitment patterns. First, regarding violent behavior, ideology can act as a restraining factor for committing (sexual) violence against civilians. For example, leaders of Leftist groups may calculate that committing sexual violence would contradict the propagated gender equality and, thus, delegitimize their state project of a new social order (Wood 2009, p. 141). In contrast, the Islamic State (IS) used its ideology to justify the attempted genocide of the Yazidi minority in Iraq, and more specifically the systematic enslavement and rape of Yazidi women (Vale 2020). There is also evidence that ideology influences whether violence committed against civilians is discriminate or indiscriminate (Thaler 2012). Secondly, ideology affects an armed group's institutional structure and its combatant socialization. For example, Marxism-Leninism spurred the emergence of guerrilla organizations and provided an elaborated military doctrine and strategic blueprints during the Cold War (Kalyvas and Balcells 2010). Moreover, ideology can be a means for armed groups to maintain group cohesion, to uphold the combatants' morale, and to guarantee combatants' obedience vis-à-vis orders and compliance with its norms (Weinstein 2007). Hoover Green (2017) argues that socializing combatants into a group's norms and ideology takes place via different mechanisms which themselves are in turn shaped by ideology. Third and ultimately, recruitment-related questions are affected by ideology: for example, if a group relies on forced or voluntary recruitment, and which parts of the population are eligible for recruitment (Gutiérrez-Sanín and Wood 2014, pp. 219-220). Large-N studies show that women participate more frequently in Leftist armed groups while Islamism as ideology seems to be a negative predictor (Henshaw 2016, p. 209). Wood and Thomas (2017) find that groups with gender egalitarian ideologies are statistically more likely to exhibit a high female participation since, as Luna and van der Haar (2019) argue, they seek to overcome gender inequalities.

To sum up, firstly, ideology plays a pivotal role for armed groups, for example by affecting their group behavior, the level and form of violence they deploy, and their recruitment patterns. Secondly, military masculinities do vary greatly across different ranks, operational purposes, and mission type such as peacekeeping operations. Furthermore, there is an emerging literature about forms of more equal masculinity in mostly Leftist guerrilla groups which hint at the importance of ideology for the construction of masculinities (Riley 2020). However, the question how to theorize this relationship remains unanswered so far. This is the research gap I engage with in this article. 


\section{Ideology and masculinity in armed groups}

In the following section, I develop a threefold theoretical argument on how ideology shapes the construction of military masculinities. First, I introduce Connell's (2005) concept of hegemonic masculinity highlighting its practice-theoretical implications. Secondly, I conceptualize ideology as thought practices. Ultimately, I conceptualize militaries and armed groups as total institutions in which ideology shapes the institution itself and is conveyed via socializing practices, leading to the construction and the everyday enactment of specific forms of military masculinity.

\subsection{Hegemonic masculinity and practice theory}

According to Connell (2005, p. 72), masculinity can be defined as a "configuration of gender practice". It is "simultaneously a place in gender relations, the practices through which men and women engage that place in gender, and the effects of these practices in bodily experience, personality and culture." Hence, ontologically, Connell's concept of hegemonic masculinity (2005, p. 65) is based on a practicetheoretical foundation as she notes:

practice never occurs in a vacuum. It always responds to a situation, and situations are structured in ways that admit certain possibilities and not others.

Practice does not proceed into a vacuum either. Practice makes a world.

In that vein, practices are "onto-formative" (Connell 2005, p. 80), they constitute reality and make the social world dynamic.

Based on a Gramscian notion of power ${ }^{5}$, the concept of hegemonic masculinity refers to the culturally and context-specific idealized form of masculinity. It is "defined as the configuration of gender practice which embodies the currently accepted answer to the problem of the legitimacy of patriarchy, which guarantees (or is taken to guarantee) the dominant position of men and the subordination of women" (Connell 2005, p. 77). Hegemonic masculinity, thus, is an ideal type which creates a hierarchy of different masculinities in relation to the hegemonic position and, thus, defines which other masculinities are marginalized and subordinated. Here, as Barrett (1996, p. 130), argues, institutions, such as the military, play a pivotal role therein, referring to "the process by which these groups and ideals form, the organizational situations and constraints that shape and construct these ideals and groups."

The ideal type character of hegemonic masculinity does not mean, in turn, that a majority of men necessarily embody the exact configuration nor that the most powerful men must be bearers of the hegemonic masculine position. Rather, it is the configuration of practice, i.e. masculinity, that men seek to achieve. As Connell and Messerschmidt (2005, p. 838) specify:

Thus, hegemonic masculinities can be constructed that do not correspond closely to the lives of any actual men. Yet these models do, in various ways,

\footnotetext{
5 For a further discussion of Connell's concept of power see, for example, Demetriou (2001) as well as Johannsson and Ottemo (2015).
} 
express widespread ideals, fantasies, and desires. They provide models of relations with women and solutions to problems of gender relations. Furthermore, they articulate loosely with the practical constitution of masculinities as ways of living in everyday local circumstances. To the extent they do this, they contribute to hegemony in the society-wide gender order as a whole.

It becomes clear that hegemonic masculinity always relates to specific settings and varies across cultural, organizational, class etc. contexts and across different levels (Connell and Messerschmidt 2005, p. 849). As a concept, hegemonic masculinity does not contain an a priori defined set of characteristics but relies on the routinised everyday practices "accomplished in social action" (Connell and Messerschmidt 2005 , p. 836 $)^{6}$. Hence, hegemonic configurations may overlap and share similar sets of practices, although the practices of a hegemonic masculinity in one context might also be perceived as widely inappropriate for the hegemonic masculinity in another context. Again, Barrett's (1996) study of the US Navy is illustrative: he finds that different occupations rank differently in relation to the hegemonic ideal of military masculinity. While naval aviators come closest to the hegemonic ideal in the military, embodying "aggressiveness, technical mastery of complex machinery, courage, and autonomy" (Barrett 1996, p. 134), especially supply officers carry lower statuses, having less opportunities to prove their manliness. Moreover, all the different expressions of masculinity, of naval aviators, of naval officers and of supply officers, share certain features of the hegemonic military masculinity like perseverance or technical mastery. However, the bravery and heroism of naval aviators might not be suitable for naval officers responsible for navigating a ship, let alone be appropriate in other work contexts outside the military institution.

Moreover, following Connell and Messerschmidt (2005, p. 848) "[g]ender is always relational, and patterns of masculinity are socially defined in contradistinction from some model (whether real or imaginary) of femininity". Therefore, constructions of femininity as well as of "women are central in many of the processes constructing masculinities-as mothers; as schoolmates; as girlfriends, sexual partners, and wives; as workers in the gender division of labour; and so forth" (Connell and Messerschmidt 2005, p. 848). For example, studies show that military masculinities commonly rely on the devaluation of women and the supposedly feminine (cf. Morgan 1994). The image of the strong and brave soldier is dependent on the contrast foil of the emotional and weak woman whereby strategies of feminizing certain traits and behaviours are also used in military training.

Theoretically, Connell's hegemonic masculinity speaks to the recent practice turn in social theory (Schatzki et al. 2001) and in International Relations (Bueger and Gadinger 2015) as for both, Connell and practice theorists, practices form the small-

\footnotetext{
${ }^{6}$ It is commonly criticized that empirical studies based on the concept of hegemonic masculinity use it rather to describe a fixed set of characteristics instead of a heuristic device to "explicitly recognize the layering, the potential internal contradiction, within all practices that construct masculinities" (Connell and Messerschmidt 2005, p. 852).
} 
est unit of the social and the starting point for theorizing 7 . Practice-theoretical approaches share a commitment to performativity and highlight the processual character of anything social (cf. Butler 1990). Similarly, practice theorists understand the social world as a "product of ongoing establishment, re-enactment, and maintenance of relations between actors, objects, and material artefacts" (Bueger and Gadinger 2015, p. 453). In this article, I follow Reckwitz (2002, p. 249) and define practice as "a routinized type of behaviour which consists of several elements," including bodily and mental activities, the use of artefacts as well as a certain form of background knowledge.

Background knowledge cannot be reduced to a mere knowing-how or knowingthat, and is not only what makes a practice doable by providing the instrumental know-how to reach a certain end. Rather, it is always embedded in practice "which it embodies, enacts, and reifies all at once" (Adler and Pouliot 2011, p. 7). Background knowledge is a "knowing from within" (Bueger and Gadinger 2015, p. 452). It renders practices intelligible and provides an "intersubjective backdrop that sets the terms of interaction [and] defines a horizon of possibility" (Adler and Pouliot 2011, p. 17). Broadly speaking, background knowledge defines which practices are socially appropriate and intersubjectively meaningful, and makes practices recognizable and understandable for spectators.

I argue that gender is located in this background knowledge: it enables to recognize and interpret the gendered character of practices and, thus, the "doing of gender". To give an example, recruits who fail to live up to the manly standards in the US Navy are reportedly targets of gendered insults. The sexist practice of insulting recruits as "girls, pussies, weenies and wimps" (Barrett 1996, p. 133) is only feasible because of an unwritten, shared understanding that women would naturally be more inclined to complaining as well as physically and mentally not strong enough to endure military training and combat. It is against the backdrop of this background knowledge which equates women with weakness, that the devaluation of femininity takes place in the military. Secondly, these routines form part of a wider configuration of practice (masculinity) in the given institutional context: here, the military masculinity is constantly enacted and reproduced as the hegemonic form by contrasting manliness with femaleness, cultivating heterosexism and homophobia (Morgan 1994, p. 167).

\subsection{Ideology as background knowledge}

Returning to the aim of the article to theorize ideology and masculinity in armed groups, I furthermore conceptualize ideology as a form of background knowledge. More specifically, I conceive of ideology as a communal practical enterprise of thought practices. Freeden (2000, p. 304) specifies:

\footnotetext{
7 However, not only Connell but also other Feminist theorists such as West and Zimmerman's (1987) "doing gender" approach can be thought of as practice theorists. Especially Butler's (1990) focus on gender as a constant repetition of performative acts is often considered as part of practice-theoretical reasoning (cf. Wilcox 2017).
} 
[I]deologies are sets of specific thought-practices whose content and morphology differ from one ideological family to another. To analyse an ideology [...] is to categorize, elucidate and decode the ways in which collectivities in fact think about politics, the ways in which they intentionally practice the art of political thinking, and unintentionally express the social patterns which that kind of thinking has developed.

Ideology, then, is expressed, consciously or unconsciously, in the everyday practices of individuals and groups. Although ideologies can guide practices implicitly, i.e. not being thought actively, at least at some point in history, ideologies must be explicitly thought. But only through the everyday practices, ideology gains its efficaciousness and, thus, is being constantly reproduced and reshaped.

Some further clarifications are necessary: first, ideologies as thought-practices are directed at political behaviour, or "action-oriented" (Sartori 1969, p. 399). In that sense, they explicitly prescribe what to do in what situation. Secondly, ideologies are normative for they, on the one hand, aim at building, maintaining or restoring a particular political or social order; they contain a specific vision of how the world should look (Gutiérrez-Sanín and Wood 2014, p. 215). In this broad sense, ideologies, hence, encompass political ideologies like Conservatism or Marxism, religious ideologies like Jihadism and broader ideological structures like neoliberalism. On the other hand, ideologies set a moral framework to assess people's behaviour and judge their actions right or wrong. Finally, with regard to my argument about ideology and military masculinities, it is important to consider how ideology and gender are related. Above all, every ideology contains ideas about gender relations, be they explicit or implicit. This entails that even if an ideology does not formulate explicit statements about gender, it still relies on implicit understandings of gender and notions of these terms. As Cockburn (2001, p. 14) notes: "gender is so normal that it goes unexamined." ${ }^{8}$ For example regarding political ideologies, Conservatism is associated with traditional attitudes towards family, marriage and gender roles (Lye and Waldron 1997), and, more explicitly, antifeminism is a key element in rightwing politics and right-wing extremism (Berg 2019).

Summing up the two previous subsections: both masculinity and ideology are understood as practical background knowledges and are constantly enacted, embodied and reproduced by the members of a specific group, in my case armed groups. Conceived of as background knowledge, masculinity and ideology are co-constitutive: ideology relies on either explicit or implicit assumptions about gender and masculinity. Equally, masculinity always contains ideas related to broader ideologies?.

\footnotetext{
8 The invisibility of gender is an effect of the presumed naturalness of gender differences. Where gender differences are rendered as natural and biologically given, they become blurred and more difficult to perceive. For example, this is the case for the division of labour in capitalist societies along presumed naturally innate capabilities like empathy and emotional capabilities needed for care work.

9 However, in this article I concentrate on the influence ideology has on masculinity constructions and do not consider the effects of gender relations on ideologies.
} 


\subsection{Socialization and ideology}

In this subsection, I make the twofold argument that ideology, first, affects the form of armed group understood as total institution itself, i.e. its organizational structure and institutional practices. Secondly, ideology is conveyed as a particular form of background knowledge in processes of military socialization. Ideology, thus, shapes the specific form of hegemonic military masculinity.

I conceptualize armed groups as total institutions which provide the institutional context of socialization processes (Barrett 1996; Felices-Luna 2011; Messerschmidt 2018). Following Goffman (1961), I understand a total institution as a theoretical ideal type whose total character can vary to different degrees. Total institutions are characterized by four features: first, the strict separation of an inside and an outside of the institution whereas inmates, or members of the institution, have only restricted contact with the outside world (Goffman 1961, p. 315-316). Secondly, the total institution penetrates every aspect of the inmates' lives whereas the separation between the private and the public sphere is abolished, hence the total character. Thirdly, the total institution aims at stripping off inmates' former identities and to let them undergo a "mortification process of the self" (Goffman 1961, p. 317) when entering the institution. Thus, formerly held social statuses are made unimportant and new identities created according to the purpose of the institution ${ }^{10}$. Fourthly, total institutions are characterized by an elaborate system of formal and informal rules, privileges and rewards for compliance or showing good spirit, as well as punishments for breaking these rules. Thus, "cooperativeness is obtained from persons who often have cause to be uncooperative" (Goffman 1961, p. 322-324). This privilege system "provides the chief framework within which the reassembly of the self takes place" and, therefore, is essential when considering the new recruits' socialization into the army. For both, performances of ideology and masculinity, remain little room for divergence in the context of total institutions.

My argument is based on the premise that, whether state militaries or rebel forces, all armed groups will display the main characteristics of a total institution to a varying but at least basic level ${ }^{11}$. As Barrett (1996, p. 132) reminds us "socialization [in the military] is pervasive: recruits are 'cut off from wider society' and live in an enclosed 'formally administered round of life'." Furthermore, the military actively operates as a gendering institution: "Since upholding a hegemonic ideal of masculinity takes collective effort, [it is] the organizational rules, practices, and

\footnotetext{
${ }^{10}$ This is not to say that other identity markers like race, class and ethnicity do not inflict on military identities and individual experiences. For example, Grosswirth Kachtan (2019) discusses how different ethnicities within the Israeli Defence Forces leads to specific masculinities. Also, the form of recruitment affects the socialization process. The Revolutionary United Front (RUF) in Sierra Leone, for example, was careful to cut all the ties of child combatants with their former lives.

11 Being aware of empirical differences, e.g. regarding organizational structure, recruitment and institutional aim, for analytical purposes I do not further distinguish, for example, status quo from status opposing groups, state militaries from armed groups or guerrilla from rebel groups. All these institutions share the institutional purpose of collectively and violently engaging with other such groups and, hence, are characterized by their militarized context.
} 
structures, particularly the systems of ranking and testing, that contribute to the construction of the hegemonic ideal" (Barrett 1996, p. 141).

As the civil war literature suggests, ideology has a major impact on an armed group's organizational structure (Kalyvas and Balcells 2010), institutional practices and division of labour and, thus, influences how exactly an armed group is a total institution. Regarding organizational structure, it defines for instance the relationship between leader(s) and members, whether it is more hierarchical or egalitarian. Institutional practices, understood broadly as all practices enacted by the institution itself, encompass inter alia socializing practices which vary according to ideological beliefs. Ultimately, the division of labour within an institution is also shaped by ideological and gender considerations (cf. Connell 2005), for instance whether women are allowed and to which roles they are ascribed based on presumed capabilities. For example, debates about integrating women into the US military were characterized by the fear that women would undermine the operational capabilities of the fighting forces (Stachowitsch 2013).

It is in the context of armed groups as total institutions, I argue, where combatants are socialized not only into a masculine ideal but also into a specific ideological framework, be it implicit or explicit, which stands in a co-constitutive relationship with masculinity constructions as laid out above. Socialization can be defined "as a process of inducting actors into the norms and rules of a given community, the endpoint of which is internalization. Socialization [...] is a process whose intended result is [...] a deeper change in an actor's sense of self" (Checkel 2017, p. 594). Moreover, socialization can reach varying degrees: from no internalization of the group norms (type 0), to rather habitual adaptation to and learning of group norms (type 1) and a full internalization of and identification with group norms (type 2) (Checkel 2017, p. 597). As Messerschmidt (2018, p. 480) reasonably argues "socialisation [sic!] within these institutions is far reaching and frequently constitutes a change in identity." Accordingly, I assume that in armed groups as total institutions, full (type 2) and partial (type 1) socialization processes are the most common ones.

After these remarks on socialization, I now turn to the socializing practices, answering how armed groups convey ideology and masculinity. Nonetheless, I argue that ideology is not only conveyed and enacted as background knowledge via the following institutional practices but also affects these institutional practices in the first place. Here, I find it useful to follow Hoover Green's (2017) categorization of four socializing practices in armed groups ${ }^{12}$ :

1. Ideological education is the most obvious institutional practice most armed groups enact to socialize their members into group ideology. In some cases, political education "explains specific social or political purposes of a particular conflict, and connects conflict purposes to specific behavioural [sic!] norms" (Hoover Green 2017 , p. 690). In other cases, this will take the form of religious teachings, prayers etc. Set in a total institutional context, participation will often be mandatory for

\footnotetext{
12 Nevertheless, it is important to note that these do not represent a closed typology of socialization practices. Rather, I use these them here as a conceptual starting point.
} 
group members and space for deliberation limited. For example, the Nepalese PLA taught its combatants about Maoist ideology, women's rights and equality of genders and castes (Riley 2019).

2. Recruitment and initiation practices: recruitment presents a pre-selection of future combatants and decides over "the initial mix of attitudes [...] as well as group members' initial social hierarchies [...]” (Hoover Green 2017, p. 689). Depending on ideology, armed groups decide whom and how to recruit, for example educated and ideologically committed students or peasants and members of the working class, only men or men and women equally, and voluntary participation or forced recruitment. Formal and informal initiation practices further socialize newly recruited combatants into the group's ideology and its gender regime, for example, initiation and bonding rituals (Barrett 1996), or sexual violence and rape rituals to attain group cohesion (Wood 2009). Similarly, Cohen (2013) finds that sexual violence and gang rape is mainly used in the case of groups that rely on forced recruitment. ${ }^{13}$

3. Once part of the group, military training presents one of the most vital sets of practices for armed groups as it aims at creating individuals who are capable of killing other individuals and sacrificing themselves (Cockburn 2001, p. 46; Higate 2003 , p. 29) and, thus, enable the total institution to fulfil its purpose of waging war. Depending on the group's ideology, military training varies greatly: it may consist only of a short instruction on handling a gun, suicide belt etc., or comprise a highly elaborate bootcamp, teaching skills as well as tactics, for example clandestine guerrilla warfare (Hoover Green 2017, p. 689). Training practices often encompass physical activities which are directed at shaping the soldiers' bodies and reinforce the linkage between masculinity and physical fitness (cf. Morgan 1994, p. 167).

4. The last set of institutional practices relevant to socializing members are disciplinary practices which serve the enforcement of specific behavioural norms and rules. Combatants have to play by the group's rules to constantly enact its ideology and gender ideals, and to preclude other background knowledges and practices from being established. The degree to which disciplinary practices are enforced depends on the administrative strength of the total institution. An armed group's stance on sexual violence among its members and non-members helps to illustrate the linkages between ideology, masculinity and disciplinary practices: do ideological beliefs contradict or encourage sexualized violence? Is sexual violence prohibited and prosecuted, tacitly or even openly tolerated, or concealed (Marks 2013)? Does the group promote, allow, or suppress the objectification of women's bodies (Maxwell 2010, p. 112)? Does the group differentiate between sexual violence against ingroup and outgroup members (Wood 2009) or is rape even deployed as a weapon of war?

In the end, I argue that it is via these socialization processes that not only masculinities are carefully constructed but that these gender constructions are thoroughly

${ }^{13}$ I would add that, in line with the previously summarized findings, part of the equation of explaining sexual violence is the lack of a restraining ideology. 
shaped by ideological thought. I suggest that these theoretical considerations offer a helpful heuristic for studying ideology and military masculinity that former works have not touched upon. Taking institutional practices like organizational structures or divisions of labour as well as the four socialization practices as analytical starting points directs the view to practices through which the ideologized character of masculinity and its enactments become visible.

\section{Illustrative example: the guerrilla masculinity of the salvadoran FMLN}

In the following subsection, I illustrate the added value of incorporating ideology as a factor for analyzing military masculinities by looking at the Salvadoran FMLN. The FMLN presents a good example for illustrating how ideology affects the construction of a military masculinity for several reasons. First, the group's MarxistLeninism provides a manifest political ideology whose effects on the form of military masculinity constructed by and enacted within the group are clearly visible. Exemplary are the high participation of women in the guerrilla struggle, figures estimate the female percentage to be around $30 \%$ of the guerrilla's total strength (Navas 2007 , p. 3), and the diverse roles these women inhabited in the FMLN. Secondly, the FMLN, women's participation and their legacy have been the subject of numerous studies providing abundant primary interview data (cf. Vázquez et al. 1996; Luciak 2001; Kampwirth 2002, 2004; Shayne 2004).

Ultimately, as I supposed in the theory section, the FMLN can be regarded as total institution: once part of the guerrilla, members of the group were cut-off from wider society "en las montañas" (Vázquez et al. 1996), life in the guerrilla strictly followed the demands and routines set by the guerrilla, rules were formulated as "revolutionary law" and enacted within a disciplinary system.

Some caveats are necessary: first, the following empirics serve only to illustrate the usefulness of the theoretical argument I made in the preceding chapter. Hence, neither is this a comprehensive case study since it cannot accommodate the complexities and ambiguities of masculine/feminine practices within the FMLN, nor do I elaborate on a definite methodology to analyze ideology and military masculinities. Secondly, against this background, it is justifiable not to work with new empirical data but to rely on the extensive secondary literature. These studies often provide interview data as a reliable source for analyzing practices from within the guerrilla. Ultimately, there are some limitations in terms of scope. While it is reasonable to assume that the effects of ideology on masculinities are most visible in groups which explicitly endorse a particular ideology like the FMLN or the Nepalese PLA (Luna and van der Haar 2019; Riley 2019), I would argue that some form of ideology is at play in all armed groups, be it in guerrillas, Jihadist groups or in state armies, and affects the respective military masculinity. Even in the case of the RUF in Sierra Leone, famous for being the prototypical predatory rebels, the social composition of lumpen youth formed a protest masculinity against social, economic and gendered 
exclusions, which were addressed, albeit only loosely, by a revolutionary ideology (Duriesmith 2014) ${ }^{14}$.

I begin the illustrative example by sketching out the socio-historical context of the Salvadoran civil war before briefly describing the FMLN's ideology. Then, I examine how an ideologized guerrilla masculinity is enacted within the FMLN. To that end, I suggest that the discussed institutional practices from the previous section provide a good analytical starting point for analyzing ideology and masculinity. Hence, I look at the group's organizational structure, its division of labor and its socializing practices, namely political education, recruitment, military training and disciplinary practices.

\subsection{Socio-historical context and FMLN ideology}

The Salvadoran civil war lasted from 1980 to 1982 between the FMLN guerrilla and a military dictatorship. The military took control of the state in 1932 and formed an informal alliance with the so-called coffee oligarchy, a mainly white liberal elite which owned almost the entire agricultural land. This alliance consisted of a complex system of power sharing to secure the elites the economic exploitation of the country's working force while maintaining a democratic masquerade (Ching 2016, p. 30). In the 1960 and 1970s, the country experienced an increasing mass mobilization with Christian base communities, inspired by Liberation theology, labour unions, student and peasant associations at its heart (Mason 1999, p. 184f.). However, society's demands to overcome social inequality and political exclusion was met with amounting, indiscriminate political violence. In response, the five guerrilla groups FPL, ERP, RN, PRTC and FAL/PCS formed the FMLN in late 1980.

The main ideological pillars of the FMLN were its struggle for Socialism and a Marxist theoretical framework of analysis. According to the latter, reformism and social democracy were rejected due to the impossibility "to achieve democracy, social justice, and progress for the benefit of the popular sectors within the limits of capitalism" (Allison and Alvarez 2012, p. 95). Instead, the FMLN build on "the construction of the Salvadoran state as the enemy of the people, the belief in armed struggle as the only way of toppling it and 'political-ideological proletarization' for revolutionaries to be able to offer the sacrifices required" (Sprenkels 2019, p. 541). Moreover, the FMLN endorsed the Leninist idea of democratic centralism "which views the party as the embryo of the new revolutionary political order, emphasizing centralized decision-making" (Sprenkels 2019, p. 542). However, differences remained between the factions regarding the appropriate military strategy and the question of negotiations with the regime, especially in the first phase of the war (Sprenkels 2019, p. 542; Allison and Alvarez 2012, p. 96). While the FPL favoured a prolonged people's war, based on the Chinese and Vietnamese experiences, the other factions opted for a mass insurrection and a quick uprising. After internal tensions, the FMLN took a more moderate course after 1984, established a "civilpolitical front” developing links with civil organizations (Sprenkels 2019, p. 542),

\footnotetext{
14 In line with my argument, Marks (2013) traces how a weakening ideological commitment and insufficient disciplinary practices can explain varying levels of sexual violence.
} 
and settled on pursuing negotiations to build a broad government of national unity (Alisson and Alvarez 2012, p. 96).

Previous research finds that the FMLN constructed masculinity around classconsciousness and their capabilities regarding armed struggle which-at least on the surface-overrode gender inequalities and gave rise to a comrade identity:

[T]hese masculinities are not based on the devaluation of women in general, but on the temporary construction of particular guerrilla femininities, which allow male-female bonding and comradely complicity, and unveil expressions of guerrilla masculinities beyond the predominant association of men with violence. (Dietrich Ortega 2012, p. 491).

It becomes apparent that ideology played a key role in shaping the hegemonic form of masculinity within the FMLN which I illustrate in the following subsection.

\subsection{The guerrilla masculinity of the FMLN}

In order to demonstrate added value of my theoretical argument, I touch upon the organizational structure (1), the division of labor (2) as well as the four socializing practices (3-6) of the FMLN. These provide a good analytical starting point for analyzing how ideology and masculinity are embodied and conveyed in these practices. Moreover, due to the relational character of masculinities, a crosscutting focus is placed on women and femininities in the FMLN.

First, I turn to the organizational structure of the FMLN (1) and how it is related to ideological and gender issues. According to Luciak (2001, p. 34f.) "the ideological and thus organizational structure of the FMLN was rigidly patriarchal and hierarchical" (cf. Vázquez et al. 1996). The ideological concept of the guerrilla as the revolutionary vanguard "which is imbued with, and entitled to, unchallenged authority to lead" (Shayne 2004, p. 34) gave reason to this hierarchical organizational form. Exemplary in this regard is the position of the five women's organizations which were founded between 1984 and 1985 affiliated to each faction (Kampwirth 2004 , p. 77-80). The increasing awareness in these organizations about womenspecific issues and their subsequent agitation for internal changes were confronted with skepticism and sabotage by the political leadership of the FMLN. The word feminism was prohibited. The gender blindness within the FMLN stemmed from Marxist-Leninist ideology, especially from the idea of a revolutionary utopia according to which

the equality desired for the future existed already in the revolutionary nuclei, where all types of differences were decreed eliminated, for example, those existing between men and women ... With such a conviction, the leadership of the guerrilla groups rejected the validity of an analysis [focusing] on the different situations of men and women within the group (Vázquez et al. 1996, p. 63).

This is in line with the "efforts of insurgent organizations in constructing a gender regime that silences gendered differences and dilutes gendered dichotomies through comrade identity" at the individual level (Dietrich Ortega 2012, p. 493). Thus, the 
organizational structure is largely shaped by ideology and reflects the vanguard ideal of guerrilla masculinity.

Secondly, the division of labor of the FMLN (2) was remarkably equitable. Internally, positions were equally open to male as well as female comrades which allowed women to rise in rank and occupy high political and military positions. In fact, more than half of the women were combatants, a category which also includes support roles while around 30\% counted as political personnel (Luciak 1999, p. 47). One fifth of the FMLN leadership, military as well as political, consisted of women (ibd.). Ibañez (2001, p. 126), a former guerrillera, generally describes the revolution as a "project of social and political transformation, instilling new values in young men and women and proving, in practice, that it is possible for a woman to be successful in areas traditionally reserved for men." As with recruitment, revolutionary ideology and the propagation of equality would not have been compatible with upholding a traditional division of labor. Personal skills and individual capacities valuable for the revolutionary project were regarded as more relevant than "inherent" gender constructions (Dietrich Ortega 2012, p. 494). However, and despite the general openness, most tasks performed by women were rather support-oriented, such as logistics, communications, food distribution and preparation, as well as first aid and health services (Shayne 2004, p. 36). Again, in this regard, revolutionary ideology informed gender relations within the guerrilla: it allowed for the large participation of women but, as Guevara recommended in his handbook Guerrilla Warfare from 1961, women were ascribed mainly support tasks (Luciak 2001; Shayne 2004).

After having discussed how ideology shaped the form of the FMLN as total institution, I now turn to the socializing institutional practices to scrutinize how these were formed by ideology and how the guerilla masculinity translates into daily life. Political education (3) played a major role of socialization to teach Marxist-Leninist ideology and raise the combatants' class consciousness, although the emphasis and content initially varied across FMLN factions (Hoover Green 2017, p. 695). There existed written curricula covering topics like Salvadoran national and economic history, Marxism and revolutionary ideology (Harnecker 1991, p. 40). The form of teaching varied from formalized instructions and the written curricula to rather informal meetings (Hoover Green 2017, p. 695). Political education aimed at the individual development of a revolutionary consciousness, fully internalizing the comrade identity. Hence, political education served to socialize recruits into Marxism-Leninism and to convey the necessary background knowledge to fight as a revolutionary rebel.

Regarding recruitment practices (4), women were actively recruited by the FMLN with a varying percentage between 27 and 34\% across the factions (Navas 2007, p. 3). Even if recruiting women was driven by instrumental reasons, as critics would argue (Vázquez et al. 1996; Luciak 2001), this was only rendered possible in the first place by a change in revolutionary ideology, the shift from the "foco" strategy of the Cuban revolution, i.e. small scale insurgencies, to mass mobilization (Kampwirth 2002, pp. 9, 14). A higher female participation affected gender relations and masculinities within the guerrilla: "Male guerrillas had to overcome their sexism, at least to the extent of inviting women into their ranks, if they were to succeed with their mass mobilization strategy" (Kampwirth 2002, p. 33). Ultimately, the FMLN 
did not rely on forced recruitment, instead many combatants reported to have joined the guerrilla because of an "ideological awakening" (Hoover Green 2017, p. 693). Thus, ideology decisively shaped the form of recruitment practices, allowing the incorporation of women. With regard to military training (5), ideology seems to have had little effect. It was reported to be quite similar to Salvadoran military training and consisted of physical training and routinization. Notably, recruits reported less injuries than state ex-combatants in El Salvador and "recognized the harsh conditions as necessary and fair" (Hoover Green 2017, p. 694).

Disciplinary practices within the FMLN (6) are particularly interesting regarding sexualized violence. While sexual violence against the civilian population was rare, it was a more common phenomenon within the guerrilla. Many female combatants tell about widespread sexual violence within the FMLN (Vázquez et al. 1996, p. 180). In many instances, male combatants took advantage of their power positions which was officially condoned by leaders who often were involved in sexual harassment themselves (Herrera 2010, p. 294). Officially, according to the so-called Revolutionary Law, rape was strictly forbidden, and perpetrators of rape were sentenced to death, regardless of the victim being either civilian or a member of the guerrilla. However, this rule was not applied consistently, and negative gendered implications were often not considered (Herrera 2010, p. 293). In this case, disciplinary practices regarding sexual violence within the guerrilla reveal both the importance as well as the limits of ideology. Although sexual violence contradicted the egalitarian ideology, the FMLN did not manage to handle the problem vis-à-vis persistent machista practices.

To sum up, the guerrilla's institutional practices as well as its organizational structure and division of labor are influenced by ideological thought, they reflect and enact the hegemonic form within the guerrilla. Thus, combatants are socialized via political education, recruitment patterns and disciplinary practices into the rather egalitarian Marxist-Leninist ideology of the FMLN and adapt to the comrade identity. As a result, forms of masculinity and femininity break with societal gender norms allowing women to participate and rise in ranks and, thus, appear to be more equitable than a supposedly societal hegemonic masculinity clustered around machismo. In that sense, the guerrilla masculinity in the FMLN can be regarded as a counter-hegemonic masculinity to the societal construction of masculinity.

However, ideology also restrained equality within the FMLN due to the hierarchical organization and the diluting effect it had on gender dichotomies. Moreover, sexual violence posed a serious problem in the guerrilla. Against the backdrop of my theoretical argument, the case of the FMLN shows how ideology and masculinity are inseparately linked, given the guerrilla's straightforward Marxist-Leninist political ideology. By looking at institutional practices in the guerrilla, it becomes clear how ideology and gender shape these practices and interact in the socialization of combatants. 


\section{Conclusion}

In this article I argued that ideology affects the form of masculinity in an armed group. Hegemonic masculinity and ideology can both be conceptually located in what practice theorists call background knowledge. I made the twofold argument that ideology, first, affects the form of an armed group as total institution, its organizational structure and institutional practices itself. Secondly, ideology is conveyed as a particular form of background knowledge via socialization practices at the individual level. In the end, it is via these same socialization processes that not only masculinities are carefully constructed but that these gender constructions are thoroughly shaped by ideological thought.

I suggest that this conceptualization of the relationship between ideology and the masculinity in armed groups enables us to better understand different military masculinity constructions across different ideological setups and how to conceptually grasp these processes. First and foremost, I argue that differences in ideology account for different forms of masculinity within armed groups. Second, as the group's socialization practices vary, so will the degree to which combatants have internalized ideology and gender norms of that group. Finally, and corresponding to the ideas of socialization and total institutions, the ideologized military masculinity is also dependent on the degree to which an institution is "totalized". Simply put, some armed groups will not have the organizational capacities to provide the level of indoctrination necessary for a full internalization of ideology.

Moreover, highlighting the practice theoretical underpinning of masculinity and ideology, especially the notion of background knowledge, brings further methodological advantages. Since background knowledge is expressed in practices, including interactions with artefacts, practice theoretical methodology not only allows for, but often urges us to use a variety of different methods and to triangulate data. For example, participant observation is usually regarded as the go-to method but seems hardly feasible in a (post-)conflict or military setting, so the second-best way to grasp the hidden meaning of practices is conducting interviews. Analyzing masculinity and ideology in armed groups then entails conducting interviews with (former) combatants, elucidating the daily routines and how life was organized in the group, while ideology and notions of masculinity will also be manifested in artefact documents like curricula, manifests, handbooks, etc. The institutional and socializing practices I discussed in this article can be good analytical starting points for analyzing how ideology and masculinity merge.

However, these theoretical considerations have to remain rather suggestive and point to the need of further empirical investigation. Here, this paper can lay the methodological groundwork for rich empirical analyses of ideologized military masculinities, allowing to focus on both, on the different institutional practices like a group's organizational structure, the division of labor as well as the socializing practices, as well as on the socialization processes within the armed group and the everyday embodiments of ideologized masculinity. Interesting cases could be the Kurdish YPG (cf. Shahvisi 2021) or Jihadist armed groups. Comparative studies analyzing masculinities in armed groups of different ideologies would also be promising in order to further illuminate the conditions under which military mas- 
culinities are being linked to violence. However, some conceptual challenges remain: for example, it needs to be clarified theoretically how ideology and military masculinities interact across different levels (cf. Quest and Messerschmidt 2017) as well as how to empirically grasp these interactions. For example, coming back to Aslam (2012), further research should illuminate what role a societal gender order plays for the ideology an armed group adapts and, hence, what specific form of military masculinities is being constructed.

Ultimately, accounting for the ideological part of military masculinities in postconflict reconstruction efforts and their specificity for DDR programs therein presents another fruitful field of research (cf. Theidon 2009). Interesting questions to investigate would be if some ideologies present specific challenges to reintegration, for example with regard to potentially varying degrees of post-conflict domestic violence across different ideological setups of armed groups. It could be assumed that the effects of ideologized masculinities also depend on the outcome of the conflict and how they match the societal norms ex-combatants reintegrate into. Simply put, a victorious guerrillero's masculinity will have a different trajectory than a disillusioned Jihadist's. Furthermore, as Riley (2019, p. 561) suggests, more equal masculinities can be a powerful resource in building sustainable peace. However, it remains unsure how durable these forms of masculinities are, since as Dietrich Ortega (2012) notes, they are only temporal arrangements. Future research should analyze how exactly more equal masculinities can be used as a resource and to what extent they can help to overcome patriarchal gender orders (cf. Myrtinnen 2018).

Acknowledgements I owe gratitude first and foremost to my wonderful colleagues Hendrik Quest and Maike Messerschmidt as well as to my supervisors Andreas Hasenclever and Gabriele Abels who encouraged me to put my thoughts onto paper and write this article. Furthermore, I thank Maike Messerschmidt, Tobias Weiss, Hendrik Quest, Andreas Hasenclever and Gabriele Abels for their challenging but extremely helpful feedback on earlier versions of this article. Ultimately, I thank the two anonymous reviewers for their valuable feedback.

Funding This work was supported by the German Research Foundation/Deutsche Forschungsgemeinschaft (DFG) under grant 425705778.

Funding Open Access funding enabled and organized by Projekt DEAL.

Open Access This article is licensed under a Creative Commons Attribution 4.0 International License, which permits use, sharing, adaptation, distribution and reproduction in any medium or format, as long as you give appropriate credit to the original author(s) and the source, provide a link to the Creative Commons licence, and indicate if changes were made. The images or other third party material in this article are included in the article's Creative Commons licence, unless indicated otherwise in a credit line to the material. If material is not included in the article's Creative Commons licence and your intended use is not permitted by statutory regulation or exceeds the permitted use, you will need to obtain permission directly from the copyright holder. To view a copy of this licence, visit http://creativecommons.org/licenses/by/4.0/.

\section{References}

Adler, Emanuel, and Vincent Pouliot. 2011. International practices. International Theory 3(1):1-36. https:// doi.org/10.1017/S175297191000031X.

Allison, Michael E., and Alberto Martín Alvarez. 2012. Unity and Disunity in the FMLN. Latin American Politics and Society 54(4):89-118. 
Aslam, Maleeha. 2012. Gender-based explosions: The nexus between Muslim masculinities, jihadist Islamism and terrorism. Tokyo, New York, Paris: United Nations University Press.

Barrett, Frank. 1996. The Organisational construction of hegemonic masculinities: the case of the US navy. Gender, Work and Organization 3(3):129-142. https://doi.org/10.1111/j.1468-0432.1996.tb00054.x.

Berg, Lynn. 2019. Between anti-feminism and Ethnicized sexism: far-right gender politics in Germany. In Post-digital cultures of the far-right. Online actions and Offline-consequences in europe and the US, ed. Mark Fielitz, Nick Thurston, 79-91. Bielefeld: transcript.

Bueger, Christian, and Frank Gadinger. 2015. The play of international practice. International Studies Quarterly 59:449-460. https://doi.org/10.1111/isqu.12202.

Butler, Judith. 1990. Gender trouble: feminism and the subversion of identity. New York: Routledge.

Checkel, Jeffrey. 2017. Socialization and violence: Introduction and framework. Journal of Peace Research 54(4):592-605. https://doi.org/10.1177/0022343317721813.

Ching, Erik. 2016. Stories of Civil War in El Salvador. A Battle over Memory. Chapel Hill: University of North Carolina Press.

Cockburn, Cynthia. 2001. Gendered dynamics of violent conflict and political violence. In Victims, perpetrators or actors? Gender, armed conflict and political violence, ed. Caroline Moser, Fiona Clark, 13-51. London: Zed Books.

Cohen, Dara. 2013. Explaining rape during civil war: cross-national evidence (1980-2009). American Political Science Review 107(3):461-477. https://doi.org/10.1017/S0003055413000221.

Collier, Paul, and Anke Hoeffler. 2004. Greed and grievance in civil war. Oxford Economic Papers 56(4):563-595. https://doi.org/10.1093/oep/gpf064.

Connell, Raewyn. 2005. Masculinities, 2nd edn., Cambridge: Polity Press.

Connell, Raewyn, and James Messerschmidt. 2005. Hegemonic masculinity. Rethinking the concept. Gender and Society 19(6):829-859. https://doi.org/10.1177/0891243205278639.

Demetriou, Demetrakis. 2001. Connell's concept of hegemonic masculinity: a critique. Theory and Society 30(3):337-361.

Duncanson, Claire. 2009. Forces for good? Narratives of military masculinity in peacekeeping operations. International Feminist Journal of Politics 11(1):63-80. https://doi.org/10.1080/14616740802567808.

Duncanson, Claire. 2015. Hegemonic masculinity and the possibility of change in gender relations. Men and Masculinities 18(2):231-248. https://doi.org/10.1177/1097184X15584912.

Duncanson, Claire, and Rachel Woodward. 2016. Regendering the military: theorizing women's military participation. Security Dialoge 47(1):3-21. https://doi.org/10.1177/0967010615614137.

Duriesmith, David. 2014. Is manhood a causal factor in the shifting nature of war? The case of Sierra Leone's revolutionary united front. International Feminist Journal of Politics 16(2):236-254. https:// doi.org/10.1080/14616742.2013.773718.

Fearon, James, and David Laitin. 2003. Ethnicity, insurgency, and civil war. American Political Science Review 97(1):75-90.

Felices-Luna, Maritza. 2011. Anti-establishment armed groups as total institutions: exploring transformations of the self. Qualitative Sociology Review 7(1):69-86.

Freeden, Michael. 2000. Practicing Ideology and Ideological practices. Political Studies 48:302-322. https://doi.org/10.1111/1467-9248.00261.

Goffman, Erving. 1961. The characteristics of total institutions. In Complex organizations: a sociological reader, ed. Amitai Etzioni, 312-338. New York: Holt, Rinehart \& Winston.

Goldstein, Joshua. 2003. War and gender: how gender shapes the war system and vice versa. Cambridge: Cambridge University Press.

Gonzalez-Vaillant, Gabriela. 2015. The Tupamaros: re-gendering an ungendered guerilla movement. NORMA 10(3-4):295-311. https://doi.org/10.1080/18902138.2015.1113771.

Grosswirth Kachtan, Dana. 2019. Challenging hegemonic masculinity by performance of ethnic habitus. Gender, Work and Organization 26(10):1489-1505. https://doi.org/10.1111/gwao.12401.

Gutiérrez-Sanín, Francisco, and Elisabeth Wood. 2014. Ideology in civil war: instrumental adoption and beyond. Journal of Peace Research 51(2):213-226. https://doi.org/10.1177/0022343313514073.

Harnecker, Marta. 1991. Con la Mirada en Alto: Historia de las FPL. Santiago de Chile: Ediciones Biblioteca Popular.

Henshaw, Alexis Leanna. 2016. Why Women Rebel: Greed, Grievance, and Women in Armed Rebel Groups. Journal of Global Security Studies 1(3):204-219. https://doi.org/10.1093/jogss/ogw008.

Herrera, M. 2010. From insurgency to feminist struggle: the search for social justice, democracy, and equality between women and men. In Women's activism in latin america and the caribbean: engendering social justice, democratizing citizenship, ed. Elizabeth Maier, Nathalie Lebon, 291-306. New Brunswick: Rutgers University Press. 
Higate, Paul. 2003. 'Soft clerks' and 'hard civvies': pluralizing military masculinities. In Military masculinities: identity and the state, ed. Paul Higate, 27-42. Westport: Praeger.

Holmes, Georgina. 2014. Gendering the Rwanda defence force: a critical assessment. Journal of Intervention and Statebuilding 8(4):321-333. https://doi.org/10.1080/17502977.2014.964449.

Hoover Green, Amelia. 2017. Armed group institutions and combatant socialization: Evidence from El Salvador. Journal of Peace Research 54(4):687-700. https://doi.org/10.1177/0022343317715300.

Ibañez, Ana Cristina. 2001. El Salvador: war and untold stories. In Victims, perpetrators or actors? Gender, armed conflict and political violence, ed. Caroline Moser, Fiona Clark, 117-130. London: Zed Books.

Johannsson, Thomas, and Andreas Ottemo. 2015. Ruptures in hegemonic masculinity: the dialectic between ideology and utopia. Journal of Gender Studies 24(2):192-206. https://doi.org/10.1080/ 09589236.2013.812514.

Johnston, Melissa Frances, Muhammad Iqbal, and Jacqui True. 2020. The Lure of (Violent) Extremism: Gender Constructs in Online Recruitment and Messaging in Indonesia. Studies in Conflict\&Terrorism. https://doi.org/10.1080/1057610X.2020.1759267.

Kalyvas, Stathis, and Laia Balcells. 2010. International system and technologies of rebellion: how the end of the cold war shaped internal conflict. The American Political Science Review 104(3):415-429.

Kampwirth, Karen. 2002. Women and guerrilla movements: Nicaragua, El Salvador, Chiapas, Cuba. University Park: Pennsylvania State University Press.

Kampwirth, Karen. 2004. Feminism and the legacy of revolution: Nicaragua, El Salvador, Chiapas. Athens: Ohio University Press.

Luciak, Ilja. 1999. Gender equality in the Salvadoran transition. Latin American Perspectives 26(2):43-67.

Luciak, Ilja. 2001. After the revolution: gender and democracy in El Salvador, Nicaragua, and Guatemala. Baltimore: John Hopkins University Press.

Luna, K.C., and Gemma van der Haar. 2019. Living Maoist gender ideology: experiences of women excombatants in Nepal. International Feminist Journal of Politics 21(3):434-453. https://doi.org/10. 1080/14616742.2018.1521296.

Lye, Diane, and Ingrid Waldron. 1997. Attitudes toward cohabitation, family, and gender roles: relationships to values and political ideology. Sociological Perspectives 40(2):199-225.

Marks, Zoe. 2013. Sexual violence inside rebellion: policies and perspectives of the revolutionary united front of Sierra Leone. Civil Wars 15(3):359-379. https://doi.org/10.1080/13698249.2013.842749.

Mason, T. David. 1999. Review. The Civil War in El Salvador: A Retrospective Analysis. Latin American Research Review 34(3):179-196.

Maxwell, Caitlin. 2010. Moving beyond rape as a 'weapon of war': an exploration of militarized masculinity and its consequences. Canadian Woman Studies 28(1):108-120.

Messerschmidt, Maike. 2018. Ingrained practices: sexual violence, hypermasculinity, and re-mobilization for violent conflict. Global Society 32(4):477-495. https://doi.org/10.1080/13600826.2018.1513397.

Morgan, David. 1994. Theater of war: combat, the military, and masculinities. In Theorizing masculinities, ed. Henry Brod, Michael Kaufman, 165-182. Thousand Oaks: SAGE.

Myrtinnen, Henri. 2018. Stabilizing or challenging patriarchy? Sketches of selected "new" political masculinities. Men and Masculinities 22(3):563-581. https://doi.org/10.1177/1097184X18769137.

Navas, María C. 2007. De Guerrilleras a Feministas: Origen de las Organizaciones de Mujeres Post-Conflicto en El Salvador. 1992-1995. In Segundo Encuentro Nacional de Historia, San Salvador, July $16-22$.

Ortega, Dietrich Luisa. 2012. Looking beyond violent militarized masculinities: gender regimes in Latin America. International Feminist Journal of Politics 14(4):489-507. https://doi.org/10.1080/ 14616742.2012.726094.

Quest, Hendrik, and Maike Messerschmidt. 2017. Männlichkeiten im Konflikt: Zum theoretischen Verhältnis von militarisierter Männlichkeit, militärischer Männlichkeit und Hypermaskulinität. Zeitschrift für Friedens- und Konfliktforschung 6(2):257-281. https://doi.org/10.5771/2192-1741-2017-2-259.

Reckwitz, Andreas. 2002. Toward a theory of social practices: a development in culturalist theorizing. European Journal of Social Theory 5(2):243-263. https://doi.org/10.1177/13684310222225432.

Riley, Heidi. 2019. Male collective identity in the people's liberation army of Nepal. International Feminist Journal of Politics 21(4):544-565. https://doi.org/10.1080/14616742.2019.1577153.

Riley, Heidi. 2020. Masculinity and conflict. In The Palgrave encyclopedia of peace and conflict studies, ed. Oliver Richmond, Gëzim Visoka https://doi.org/10.1007/978-3-030-11795-5_104-1.

Sartori, Giovanni. 1969. Politics, ideology, and belief systems. American Political Science Review 63(2):398-411.

Schatzki, Theodore, Karin Knorr Cetina, and Eike von Savigny (eds.). 2001. The practice turn in contemporary theory. London: Routledge. 
Shahvisi, Arianne. 2021. Beyond Orientalism: exploring the distinctive feminism of democratic confederalism in Rojava. Geopolitics 26(4):998-1022. https://doi.org/10.1080/14650045.2018.1554564.

Shayne, Julie. 2004. The revolution question: feminisms in El Salvador, Chile and Cuba. New Brunswick: Rutgers University Press.

Sprenkels, Ralph. 2019. Ambivalent moderation: the FMLN's ideological accommodation to post-war politics in El Salvador. Government and Opposition 54(3):536-558. https://doi.org/10.1017/gov.2018. 37.

Stachowitsch, Saskia. 2013. Professional soldier, weak victim, patriotic heroine. International Feminist Journal of Politics 15(2):157-176. https://doi.org/10.1080/14616742.2012.699785.

Thaler, Kai. 2012. Ideology and violence in civil wars: theory and evidence from Mozambique and Angola. Civil Wars 14(4):546-567. https://doi.org/10.1080/13698249.2012.740203.

Theidon, Kimberly. 2009. Reconstructing masculinities: the disarmament, demobilization, and reintegration of former combatants in Colombia. Human Rights Quarterly 31:1-34.

Vale, Gina. 2020. Liberated, not free: Yazidi women after islamic state captivity. Small Wars \& Insurgencies 31(3):511-539. https://doi.org/10.1080/09592318.2020.1726572.

Vázquez, Norma, Christina Ibáñez, and Clara Murguialday. 1996. Mujeres - Montaña. Viviencias de guerrilleras y colaboradoras del FMLN. Madrid: horas y HORAS.

Weinstein, Jeremy. 2007. Inside rebellion: the politics of insurgent violence. Cambridge: Cambridge University Press.

West, Candace, and Don Zimmerman. 1987. Doing gender. Gender and Society 1(2):125-151.

Wilcox, Lauren. 2017. Practicing gender, queering theory. Review of International Studies 43(3):789-808. https://doi.org/10.1017/S0260210517000183.

Wilén, Nina, and Lindy Heinecken. 2018. Regendering the South African army: inclusion, reversal and displacement. Gender, Work and Organization 25(6):670-686. https://doi.org/10.1111/gwao.12257.

Wood, Elisabeth. 2009. Armed groups and sexual violence: when is wartime rape rare? Politics \& Society 37(1):131-162. https://doi.org/10.1177/0032329208329755.

Wood, Elisabeth, and Jakana Thomas. 2017. Women on the frontline: Rebel group ideology and women's participation in violent rebellion. Journal of Peace Research 54(1):31-46. https://doi.org/10.1177/ 0022343316675025 . 